\title{
Congress and Arms Sales: Tapping the Potential of the Fast-Track Guarantee Procedure
}

\author{
Vanessa Patton Sciarra
}

The use of arms transfers ${ }^{1}$ to achieve political ends has long been a major feature of American foreign policy. Although the Iran-Contra Affair $^{2}$ is the most recent and most prominent example of this practice, arms transfers have been relied upon by every postwar administration to achieve political ends. ${ }^{3}$ However, while arms transfers have been a constant feature of American foreign policy, the form of arms exports has changed over the decades from military aid packages in the 1950's and 1960 's to sales in the 1970's and 1980's. ${ }^{4}$ This shift has led to a decreased

1. The term "arms transfers" refers to the provision of non-nuclear combat equipment, spare parts, ammunition, and support services by outright grant or by sale. A foreign government wishing to procure American-manufactured arms may receive them in three ways. First, if received as part of a foreign aid package, the arms are paid for with funds appropriated by Congress under the Military Assistance Program. See 22 U.S.C.A. §§ 2311-2322 (1979 \& Supp. 1988). Congress can directly control such transfers through its appropriation power. Second, a foreign government wishing to purchase arms may initiate discussions with the United States government under the Foreign Military Sales Program. See 22 U.S.C.A. $§ \S ~ 2761-2770 a ~(1979 \&$ Supp. 1988). In this case, the United States government acts as an agent for the sale, buying the arms from American manufacturers and reselling them to foreign governments. Under this program, loans may also be made available to some foreign governments to cover the purchase price. Third, a foreign government may seek to buy arms directly from an American manufacturer in a commercial sale. Such sales involve the United States government only in the issuance of an export license. See 22 U.S.C.A. $\S 2778$ (1979 \& Supp. 1988). In the latter two cases, under the current state of the law, Congress can only register disapproval of a pending sale late in the process, when negotiations have been completed. For a complete description of the decision-making processes involved in each type of sale, see P. HAMMOND, D. Louscher, M. SAlomone \& N. Graham, The Reluctant Supplier 83-124 (1983) [hereinafter Reluctant SUPPLIER].

2. See generally President's Special Review Board, The Tower Commission Report (1987). See also Scheffer, U.S. Law and the Iran-Contra Affair, 81 AM. J. INT'L L. 696, 698-713 (1987) (describing legal requirements not followed by Reagan Administration pertaining to sale of arms).

3. Many commentators have described the use of military assistance and arms sales by successive administrations to accomplish foreign policy goals. See, e.g., ReLucranT SuPPLIER, supra note 1, at 59-203; R. Labrie, J. Hutchins, E. Peura \& D. Richman, U.S. Arms Sales Policy 5-24 (1982) [hereinafter Arms Sales Policy]; A. Cottrell, R. Hanks \& M. Moodie, Arms TransfERS AND U.S. Foreign AND Military Policy 13-25 (1980).

4. Immediately after World War II, the bulk of American arms exports went to European allies. Later, as the foreign policy of containment led to American commitments in far-flung regions, such as Southeast Asia, military aid to these areas increased as well. ARMS SALES PolicY, supra note 3, at 6-7. By the late 1960's, the market for arms increased dramatically as developing countries sought to build military capacity. This trend led Congress to pass the Foreign Military Sales Act of 1968, Pub. L. No. 90-629, 82 Stat. 1322 (codified as amended at 22 U.S.C.A. \$§ 2751-2796 (1979 \& Supp. 1988)), which established a formal procedure for cash and credit sales, but left decision-making 
role for Congress in monitoring arms exports and has increased congressional-executive tension over the issue of arms sales. ${ }^{5}$ This longstanding tension-laid bare by the Iran-Contra Affair-will only increase as the United States continues to sell arms and Congress continues to demand an active role in setting the foreign policy agenda. ${ }^{\circ}$

This Note examines the methods Congress has previously employed to assert its role in the area of arms sales and then proposes a new, more effective control mechanism. The most recent congressional attempt to systematically monitor arms sales came in the early 1970's. ${ }^{7}$ Concerned that unregulated transfers had contributed to dangerously extensive foreign policy commitments like those in Southeast Asia, Congress passed comprehensive legislation in 1976 that was aimed at increasing its role in the arms transfer process. ${ }^{8} \mathrm{~A}$ crucial element of the new system was a number

largely to the discretion of the executive branch. ARMS SALES POLICY, supra note 3, at 8-9. Faced with an increasing demand for arms, especially from the oil-rich developing countries, the Nixon and Ford Administrations sold arms to most willing buyers. Charges that arms exports were "out of control" led Congress to pass the International Security Assistance and Arms Export Control Act of 1976, Pub. L. No. 94-329, 90 Stat. 729 (codified as amended 22 U.S.C.A. $\$ \$ 2751-2796$ (1979 \& Supp. 1988)(hereinafter AECA). See infra text accompanying notes 38-44. This legislation attempted to force executive branch restraint in sales by both strong policy language and procedural controls involving Congress. Concurrently, President Carter agreed to make arms sales an "exceptional tool" of foreign policy. ARMS SALES PolicY, supra note 3, at 10. However, arms sales continued unabated during his administration and the legislative restraint proved largely ineffective. Id. at 11; Senate Dfmocratic Policy Comm., 98th Cong., 1st Sess., An Unconventional Arms Policy: Selling Ourselves Short 8-9 (Comm. Print 1983) [hereinafter 1983 Senate Report]. Early on, the Reagan Administration committed itself to a "flexible approach," making it clear that arms sales would play an active role in its foreign policy agenda. ARMS SALES PolicY, supra note 3, at 15-18; 1983 SENATE RePORT, supra, at 17-18 (criticizing Reagan Administration's case-by-case approach to arms transfers and concomitant increase in sales volume).

5. This tension has been particularly pronounced during President Reagan's two terms because his administration has demonstrated little effort to comply with the mandate of restraint in arms sales set out in the AECA. See 1983 SENATE REPort, supra note 4, at 14-17 (documenting Reagan Administration flouting AECA policy guidelines).

6. While analysts argue over the rate at which arms sales have been increasing since the early 1970's, see Reluctant SUPPLIER, supra note 1, at 12 (discussing disagreement over terms of measurement), none argues that the volume of sales is likely to decrease in the near future. A coherent arms sales policy is critical given that demand for arms is not likely to abate in the near future. Unlike the pre-1970's period, when developing countries would gladly accept American weapons systems that were dated or obsolete, developing countries now seek state-of-the-art systems, even at the risk of incurring substantial debt burdens. 1983 SENATE REPORT, supra note 4, at 19-20. While the countries of the Middle East will probably continue to be the biggest buyers in the near future, subSaharan Africa is the fastest growing market. $I d$. at 21. Other buyers include South American and Southeast Asian countries. Id. at 22-26.

7. See supra note 4 . The assertion of a more active congressional role in foreign affairs in the wake of Vietnam and Watergate has been discussed by many commentators. See, e.g., T. FRANCK \& E. Weisband, Foreign Policy by Congress (1979); The Tethered Presidency (T. Franck ed. 1981); L. Fischer, The Politics of Shared Power (1987). The increasing number of procedures the executive branch must follow when acting in foreign affairs provides clear evidence of this trend. See Koh, Congressional Controls on Presidential Trade Policymaking After I.N.S. v. Chadha, 18 N.Y.U. J. INT'L L. \& Pol. 1191 (1986) (describing growing use of procedures in trade legislation); Meyer, Congressional Control of Foreign Assistance, 13 YALE J. INT'L L. 69 (1988) (same for aid legislation); see also Henkin, Foreign Affairs and the Constitution, 66 ForeIGN AFF. 284, 299-306 (1987) (arguing for continued congressional assertion of more central role in foreign policymaking by reliance on variety of procedures).

8. See infra text accompanying notes 38-44. In addition to increased congressional oversight over arms sales, Congress included in the AECA policy statements calling for the exercise of restraint in 
of legislative vetoes which allowed Congress to police executive branch decisionmaking. ${ }^{\circ}$ In 1983, the Supreme Court held the legislative veto procedure unconstitutional, ${ }^{10}$ leaving Congress to fall back on ad hoc solutions, such as "report and wait" periods, ${ }^{11}$ to preserve its role in foreign affairs policymaking. ${ }^{12}$ Congressional participation is particularly important in the arms sales area if the legislative branch is to influence the executive branch in setting foreign policy goals, such as a more or less aggressive arms sales policy. ${ }^{13}$

arms sales. See 22 U.S.C. § 2751 (1982).

9. The term "legislative veto" refers to statutory provisions that allow a committee of one or both Houses of Congress to "veto" executive actions taken under broadly delegated authority - that is, to disallow presidential action, usually by a majority or two-thirds vote. In 1983, when the Supreme Court declared the procedure unconstitutional, legislative vetoes were present in most statutes delegating authority to the President for the conduct of foreign affairs. See INS v. Chadha, 462 U.S. 919, 1004-14 (1983) (White, J., dissenting) (cataloguing legislative veto provisions in statutes dealing with foreign aid, trade, arms sales, war powers and emergency powers); see also Koh, supra note 7, at 1207 (legislative veto had become "congressional control method of choice in the foreign affairs realm"); Gilmour \& Craig, After the Congressional Veto: Assessing the Alternatives, $3 \mathrm{~J}$. PoL'y ANALysis \& MGMт. 373, 374 (1984) (same). Although no presidential initiatives in foreign affairs were actually challenged by a veto resolution, $i d$., the procedure did exert pressure on executive branch policymaking and its demise provoked congressional hearings and much commentary; see, e.g., infra note 47. Even if it were still a viable option, the legislative veto would not address the problem of congressional participation as well as the fast-track guarantee procedure; see infra Section II.

10. See INS v. Chadha, 462 U.S. 919 (1983) (Congress cannot accomplish legislative action without fulfilling constitutional requirements of presentment and bicameralism).

11. See text accompanying notes $46-49$.

12. Many commentators have argued that no all-purpose substitute for the legislative veto is available. See, e.g., Gilmour \& Craig, supra note 9 (discussing possible substitutes). But see Breyer, The Legislative Veto After Chadha, 72 GEO. L.J. 785 (1984) (proposing single substitute procedure). Congress has chosen to adjust statutes containing legislative vetoes on a case-by-case basis, House Comm. on Foreign Affairs, 98th Cong., 2o Sess., Congress and Foreign Policy 1983, at 137 (Comm. Print 1984) (hereinafter 1983 House RePORT], and has chosen to rely on such devices as durational limits on authorization, reporting provisions and consultation requirements. Id. at 136-37. The former two devices are cumbersome and the latter often proves ineffective without some other incentive for compliance like a guarantee of expedited treatment. See generally Franck \& Bob, The Return of Humpty-Dumpty: Foreign Relations After the Chadha Case, 79 AM. J. INT'L L. 912 (1985); see also Koh, Why the President (Almost) Always Wins in Foreign Affairs, 97 Yale L.J. 1255, 1301 (1988) (arguing that only effective supervisory methods in foreign affairs legislation have been legislative veto and appropriations cutoff). For thorough analyses of the efficacy of procedural mechanisms relied upon by Congress in specific areas, see Koh, supra note 7, at 1204-07 (devices used in Trade Act of 1974 and subsequent trade legislation include specific negotiating objectives, "sunset" provisions, and extensive consultation and reporting requirements); Meyer, supra note 7, at 83-85, 94-95 (devices in foreign assistance statutes include objective definitional standards, reporting and consultation requirements, shortened authorization periods, independent congressional factfinding bodies, and expedited legislative procedures).

13. Among academic commentators, as well as members of the political branches of government, there is a significant difference of opinion as to what role arms transfers should play in American foreign policy. For example, many agree with former Secretary of State Kissinger that arms transfers stabilize regional balances and are a primary tool of "conflict control." See Moose \& Siegel, Congress and Arms Transfers, in ARms Transfers and American Foreign Policy 228, 254-60 (A. Pierre ed. 1979); 1983 SENATE REPORT, supra note 4, at 11-14 (Reagan administration view that volume of. arms sales to developing countries is vital index of American/Soviet competition). Others feel a strong uneasiness about the United States role as one of the world's foremost supplier of arms and hope that the United States will take a stronger stance on the multilateral restraint of arms sales. Idd. at 5 (discussing potential for escalation of conflict into nuclear confrontation). Other factors that may enter the decision on a given sale include whether the weapons at issue have nuclear capability, whether importation of sophisticated weapons will disturb a regional military balance, whether purchase will increase the debt burden or significantly sap development resources, and whether the risk that the 
Against this backdrop of repeated failure to find a meaningful substitute for the legislative veto, this Note examines a procedure-developed to ensure more extensive congressional participation in the negotiation of trade agreements-that may strengthen Congress' ability to regulate arms transfers. The procedure, the "fast-track guarantee," allows the executive and legislative branches to strike a bargain: If the executive branch seeks congressional approval of its negotiating agenda early in the negotiation process, Congress will guarantee expedited treatment of any legislation necessary to validate the agreement. ${ }^{14}$ In the future, the procedure may enable Congress to exert greater control over executive action in other foreign affairs areas, specifically those areas where negotiation of executive agreements remains a crucial and unregulated part of policy implementation. ${ }^{15}$

This Note argues that Congress cannot play a meaningful role in affecting executive branch negotiations unless the President is forced to consult with congressional committees early in the process. Experience from the trade area indicates that the fast-track guarantee procedure, used at the pre-negotiation stage, will provide the executive branch with the necessary incentives to ensure such consultation. It provides both a legal constraint and a means of power-sharing that balances the policy needs of both branches.

Section I describes the constitutional scope of each branch's power to exercise control over arms transfers and reviews the three legislative regimes that have structured congressional-executive participation in this area to date. Section II then reviews the fast-track guarantee procedure as developed in the trade area. The potential application of a similar procedure to ensure a greater congressional role in the negotiation of arms sales is examined in Section III and some suggestions are made for potential use of the procedure in other areas.

weapons will fall into unfriendly hands is worth allowing the deal to go through. Warnke \& Luck, American Arms Transfers: Policy and Process in the Executive Branch, in ARMS Transfers and AMERICAN Foreign POLICY, supra, at 207-09; 1983 SENATE RePort, supra note 4, at 2. Including Congress in the debate on both the questions of which specific sales the United States should make and what its broader sales policy should be will give the ultimate decisions a legitimacy they often lack under the current system. See text accompanying notes 50-57 (describing recent congressional attempts to veto sale of arms to Saudi Arabia).

14. See infra text accompanying notes 65-71.

15. In foreign affairs, policymaking cannot be separated from the negotiation of international agreements; the initiation of discussions with foreign governments and the negotiation of formal and informal agreements all constitute policy in the making. Rather than limit presidential use of unilateral executive agreements, a Congress that seeks active involvement in foreign affairs should create legislative procedures for mandatory involvement in the agreement-making process. $C f$. Henkin, supra note 7, at 306 (Congress should react to growing use of executive agreements by careful scrutiny and use of "political weapons"). 


\section{The Congressional-Executive Balance of Power and Arms SALES}

\section{A. Constitutional Competence of Congress and the President over Arms Sales}

As in many areas of foreign policymaking, ${ }^{16}$ both Congress and the President can claim some constitutional power to authorize arms sales. United States v. Curtiss-Wright Corp. ${ }^{17}$ is often cited to support claims of broad executive powers in foreign affairs. Language in the opinion celebrates the "very delicate, plenary and exclusive power of the President as the sole organ of the federal government in the field of international relations-a power which does not require as a basis for its exercise an act of Congress. . . ."18 Supporters of a strong executive role in foreign affairs have seized on this conception and argued that the opinion confirms a constitutionally-based general foreign affairs power for the Executive. ${ }^{19}$

The general foreign affairs power, in tandem with article II's enumerated grants of power, can be read to support the President's claim to constitutional authority in the arms sales area. The commander-in-chief clause has historically been seen to provide the Executive with wideranging power over military matters even in peacetime. ${ }^{20}$ Further, the President may derive some power in this area from the grant of general

16. The Constitution provides little guidance to Congress and the President in determining who should manage foreign affairs beyond establishing, in the broadest of terms, the general areas in which each branch may act. As a result, in many foreign policy areas, including trade, economic and military aid, arms sales, emergency powers and troop deployments, strong arguments can be made for concurrent authority. See, e.g., Henkin, supra note 7 (discussing constitutional support for concurrent authority in these areas). Historically, Congress has delegated much of its authority in these areas to the President, thereby supporting the "steady growth of presidential power." Id. at 292; see L. HENKIN, FoREIGN AfFAIRS AND THE CONSTITUTION 37-44 (1972) (arguing that presidential practice has resulted in broad assertions of power which, left unchallenged, have created historical precedent for sweeping presidential power in foreign affairs); Koh, supra note 12, at 1338 (arguing that "customary constitutional law" of executive predominance has been created in foreign affairs by congressional acquiescence).

17. 299 U.S. 304 (1936).

18. 299 U.S. at 320 (dictum). But see L. HeNkin, supra note 16 , at $45 \mathrm{n} .18$ (Sutherland's reliance on John Marshall's statement that President was sole organ of federal government in foreign affairs not historically accurate since Marshall was probably referring to presidential monopoly of channels of communication and diplomatic apparatus).

19. See generally Koh, supra note 12 , at 1308 (discussing treatment of opinion as "amendmentanalogue" to enumerated powers of Article II by courts and executive branch).

20. U.S. CONST. art. II, § 2, cl. 1. See generally L. HENKIN, supra note 16, at 50-54 (reviewing history of congressional acquiescence to expansive interpretation of clause); T. FRANCK \& E. WEISBAND, supra note 7, at 63-68 (same). Though the framers probably meant the power to be used after a congressional declaration of war, Presidents have relied on the clause in peacetime. L. HeNkin, supra note 16, at 53. Presidential reliance on this power has not gone unchallenged. Compare 39 Op. Att'y Gen. 484 (1940) (President can rely on this power in arranging bases-for-destroyers deal) with Youngstown Sheet \& Tube Co. v. Sawyer, 343 U.S. 579, 587 (1952) (seizure of steel mills necessary for producing arms in times of war cannot be sustained as exercise of commander-in-chief power) and Note, The Arms Export Control Act and Congressional Codetermination over Arms Sales, 1 AM. U.J. INT'L L. \& PoL'y 291, 314 n.179 (1986) (citing hearings on arms sales legislation where Congressmen challenged scope of power). 
executive power in article II. ${ }^{21}$ Historically, Presidents have relied on the aggregation of these powers to make executive agreements covering a wide range of intergovernmental relations, ${ }^{22}$ and this power can be seen as an additional ground for assertion of executive power in this area. ${ }^{23}$

But ironically, given that dicta in Curtiss-Wright suggests an independent role for the President in foreign affairs generally, the holding in the case supports a less expansive view of the President's power in the arms sales area. The Supreme Court found that the statute at issue in that case, granting to the President the power to prohibit the sale of arms to certain countries, did not contain an unconstitutional delegation of legislative power. ${ }^{24}$ The holding thus concedes that Congress has a role to play in arms sales. The Court would have been hard pressed to argue for executive independence in the making of arms sales given the strong congressional claims to participate in arms sales. Congressional claims are derived from the foreign commerce clause, ${ }^{25}$ the "spending power," dispose of U.S. property, ${ }^{27}$ the necessary and proper clause ${ }^{28}$ and Congress' general foreign affairs power. ${ }^{29}$

Given Congress' strong textual claims to regulate arms sales, it will be rare that a President will attempt to act on independent authority in the area. ${ }^{30}$ Instead, the pressing question is how Congress should legislate so

21. U.S. Const, art. II, $\S 1, \mathrm{cl} 1$ ("The executive Power shall be vested in a President. . . .). See L. HENkIN, supra note 16 , at 43-44.

22. See generally L. HENKIN, supra note 16, at 176-87 (discussing constitutionality of sole executive agreements).

23. Note, supra note 20 , at $315-16$.

24. 299 U.S. at 324.

25. U.S. Const. art. I, $\S 8, \mathrm{cl}$. 3. The foreign commerce clause allows Congress to regulate every aspect of trade with foreign nations, including whether or not goods, including arms, are sold at all. See L. Henkin, supra note 16, at 70 ("The Commerce Power . . . might be sufficient to support virtually any legislation that relates . . . to foreign relations."); see also Note, supra note 20 , at 310 (same).

26. U.S. ConST. art. I, $\S 8$, cl. 1. The power to "provide for the common Defence and general Welfare" has been read to support arms transfers because they serve American security interests. See L. HeNkin, supra note 16, at 77 \& n.48; Note, supra note 20 , at 311.

27. U.S. Consr. art. IV, $\$ 3$, cl. 2. This power may be used to justify a variety of military transfers including the sale and transfer of arms and nuclear materials. See L. HenkIN, supra note 16 , at 77 ; Note, supra note 20 , at 310.

28. Note, supra note 20 , at $310-11$; see also L. HENkiN, supra note 16 , at $71-72,78$.

29. Perez v. Brownell, 356 U.S. 44, 57 (1958) (Frankfurter, J.) ("Although there is in the Constitution no specific grant to Congress of power to enact legislation for the effective regulation of foreign affairs, there can be no doubt of this power in the law-making organ of the Nation.") (citing Curtiss-Wright, 299 U.S. 318), overruled on other grounds, Afroyim v. Rusk, 387 U.S. 253 (1967); see also L. HENkIN, supra note 16, at 68, 74-76 (Congress can claim "an unenumerated 'foreign affairs power,' the legislative derivative of the powers of the United States inherent in its sovereignty."); Note, supra note 20, at 311 (same).

30. Especially given the present web of legislation providing for a congressional role in arms sales, it would be surprising to find a President willing to authorize an overt arms sale, like Roosevelt's destroyers-for-bases deal with Great Britain in 1941, without involving Congress. Such action would undoubtedly lead to a hostile response from Congress, probably in the form of withheld appropriations to finance the sale. See L. Henkin, supra note 16, at 79 ("Congress can readily refuse to appropriate when it believes the President has exceeded his powers."); Note, supra note 20, at 316 n.189 (same). 
as to ensure adequate scope for executive flexibility while exercising its constitutional right to participate in decisionmaking. ${ }^{31}$ The history of arms sales legislation, as in many other foreign affairs areas, has been one of successive attempts to craft statutes that allow for delegation without sacrificing participation in overall policy formulation.

The question of broad or narrow delegation of authority by Congress to the President has often been determined by the values Congress wants to maximize at a given time. The executive branch argues that diplomatic maneuvering demands the ability to make flexible responses and credible offers. Indeed, in each of the three arms sales "regimes" employed in the postwar period, Congress accepted the importance of executive flexibility and credibility by delegating broadly. However, Congress has increasingly recognized the importance of others values, principally the need for congressional oversight of executive action and congressional participation in policymaking: in the two most recent statutory regimes it has struggled to recalibrate the balance of power to reflect these values.

\section{B. Arms Sales Legislation Before Chadha}

The first regime, which lasted from 1949 to 1974, was characterized by the same type of broad delegation found in most of the foreign affairs statutes of the postwar period. ${ }^{32}$ The importance of the perception of a strong Executive, ${ }^{\text {ss }}$ coupled with the relatively small amount of arms being exported through sales, ${ }^{34}$ meant that executive needs for flexibility and credibility could be satisfied at the expense of congressional participation.

In the wake of the Vietnam War, as old assumptions about the wisdom of broad delegation in foreign affairs were challenged, members of Congress saw the need to oversee and participate in foreign policymaking. ${ }^{35}$

31. The concerns that led the Supreme Court in Curtiss-Wright to praise the use of broad delegation in foreign affairs statutes are often referred to by the executive branch: speed, flexibility and efficiency. 299 U.S. at 319-21. The assumption underlying this argument is that Congress cannot and should not micromanage policy because it cannot respond quickly and efficiently to diplomatic developments. But to say that Congress only has power to "set general policy guidelines and to disapprove particular presidential actions as inconsistent with those guidelines," Meyer, supra note 7, at 96, is to oversimplify. This Note argues that Congress can play a more meaningful role in shaping policy, while still preserving the ability of the executive branch to function, by putting teeth in the concept of consultation. See supra text accompanying notes 68-71.

32. The Mutual Defense Assistance Act of 1949, Pub. L. No. 81-329 (1949), authorized the President to approve military assistance and cash sales to foreign governments without congressional approval. Madison, The Arms Sale Say-So, 12 NAT'L J. 667, 668-69 (1987). Later, with the passage of the Foreign Military Sales Act of 1968, Pub. L. No. 90-629, 82 Stat. 1320 (1968), Congress separated arms sales from the general foreign assistance statutes but continued the practice of broad delegation. The 1968 Act did include reporting requirements, see, e.g., id. at $\S 3(\mathrm{a})(1), 82$ Stat. at 1322 (President must report sale but report not due prior to sale), but did not provide a mode of immediate congressional disallowance of executive action.

33. See Koh, supra note 12, at 1293 (describing presidential role in shaping postwar multilateral political and economic order).

34. See supra note 4.

35. See generally sources cited supra note 7. Congress enacted new legislation that sought to do more than facilitate congressional reaction to executive branch decisions. See, e.g., War Powers Reso- 
Congress passed new statutes which sought to police executive action by use of various procedural mechanisms designed for that purpose. ${ }^{38}$ The most powerful of these, the legislative veto, provided for unilateral congressional nullification of an action taken by the executive branch under delegated authority. ${ }^{37}$

The second regime in arms sales legislation began in 1974 when Congress incorporated a legislative veto into the existing arms sales framework, thereby substantially altering the balance of power between the two political branches. Passed in the wake of President Nixon's 1972 decision to sell weapons systems covertly to Iran, Saudi Arabia and Kuwait, ${ }^{38}$ the Nelson-Bingham Amendment to the Foreign Assistance Act of $1974^{30}$ provided for a two-house veto ${ }^{40}$ of reported, government-sponsored sales in excess of $\$ 25$ million. ${ }^{41}$ Congress later strengthened this legislative veto provision ${ }^{42}$ by adding tougher reporting requirements when it passed comprehensive arms export control legislation in the form International Security Assistance and Arms Export Control Act of 1976 (AEGA). ${ }^{43}$ By

lution, 50 U.S.C. $\$ \S 1541-1548$ (1982); Case-Zablocki Act, 1 U.S.C. § 112b (1982); International Emergency Economic Powers Act, 50 U.S.C. $\$ \S 1701-1706$ (1982); Trade Act of 1974, 19 U.S.C. $\$ \S 2101-2487$ (1982). The purpose was to involve Congress, through consultation and the threat of the legislative veto, in policymaking. See T. FRANCK \& E. WeISBAND, supra note 7, at 61-62 (legislation meant to create "new framework of rules for power sharing" among executive and legislative branches).

36. See supra note 12 .

37. See supra note 9.

38. Though Nixon's actions were clearly a catalyst for the 1974 Amendment, other factors contributed to congressional interest in the issue of conventional arms transfers, an interest comparable in degree to the "merchants of death" inquiries of the 1930's. See Moose \& Siegel, supra note 13, at 228-29. As early as 1973 , legislators were proposing a reassessment of the statutory framework for arms sales in light of the growing demand for cash sales. Id. at 229-32; see also supra note 4. Senator Gaylord Nelson spoke for many congressmen when he voiced concern that secret arms sales would lead to foreign commitments like those in Vietnam. Note, supra note 20, at 294 \& n.17; see also T. Franck \& E. WeISBAND, supra note 7, at 98-100 (describing details of passage of amendment).

39. Foreign Assistance Act of 1974 (Nelson-Bingham Amendment), Pub. L. No. 93-559, § 45(a)(5), 88 Stat. 1795, 1814 (codified as amended at 22 U.S.C. $\S 2776$ (1982)(amended 1986)).

40. A two-house veto required that both Houses had to pass a resolution disapproving the executive action within a specified time period in order to withdraw authority for its completion.

41. The statute required that the President report all foreign military sales and provided that Congress could disapprove of any sale by passage of a concurrent resolution in a twenty-day period after the report had been received. The Amendment also contained a waiver provision, providing that the President could forgo this procedure if he certified the existence of a national emergency. Note, supra note 20, at 295 .

42. This further amendment came in response to the Ford Administration's avoidance of the original Amendment's reporting provisions. The Ford Administration had arranged the sale of a Hawk air defense system to Jordan and only reported the planned sale to Congress at the last possible moment. Id. at 295-96. Legislators also found the Amendment provisions inadequate in that they included a dollar value "tripwire" that was too high, reporting provisions that allowed too little time for Congressional action and limits on the legislative veto to sales, not covering transfers. Id. at 296.

43. Pub. L. No. 94-329, 90 Stat. 729 (codified as amended 22 U.S.C. $\$ \S 2751-2796$ ) (1982) (amended 1986). The new reporting provisions in the AECA required that the President, before issuing a government-to-government letter of offer to sell, had to submit detailed certification explaining the proposed sale of "any defense articles or defense service under this Act for $\$ 25,000,000$ or more, or any major defense equipment for $\$ 7,000,000$ or more." Id. at $\S 211,90$ Stat. $742-43$. Congress then had thirty days to veto the sale. $I d$. In addition, all non-NATO commercial sales involving transfers of greater than $\$ 25$ million would have to be processed through this procedure rather than 
1983, subsequent amendments to the AECA had expanded the legislative veto provisions to include third-country transfers of United States arms, commercial sales, and leases of defense equipment. ${ }^{44}$

Though no proposed arms sales were successfully challenged by a concurrent resolution, Congress was able to exert some pressure on the executive branch regarding several large sales. ${ }^{45}$ The legislative veto gave Congress leverage, allowing it to threaten the executive branch with a lastminute challenge to its negotiating credibility unless the executive branch took consultation seriously.

Yet the legislative veto did not provide the most successful balance between the Executive's need for flexibility and credibility and Congress' desire for oversight and participation. While allowing Congress to oversee executive decisionmaking, Congress entered the process too late to effectively influence sales decisions. The flexibility the executive branch gained under such a scheme was also offset by the challenge to its credibility posed by a possible congressional veto of a fully negotiated deal. What was needed was a solution which allowed for congressional participation earlier in the negotiation process while concurrently giving the President a firm presence at the negotiating table.

\section{Post-Chadha Changes in Arms Sales Legislation}

In the third regime, stretching from the 1983 Chadha decision to the present, Congress has not learned the lesson of the legislative veto-that congressional participation after negotiations have been completed is ineffective and potentially damaging diplomatically-but has instead attempted to shore up the existing legislation. Chadha, in invalidating the legislative veto, raised the question of whether the AECA, without its legislative veto provisions, ${ }^{48}$ would serve as an adequate procedural constraint on the President. Pursuant to Chadha's holding, ${ }^{47}$ Congress re-

through the export licensing procedure, thereby subjecting them to a potential congressional veto. Id. By means of a "gentlemen's agreement," Congress arranged to receive pre-notification 20 days before a sale was formally reported, allowing 50 legislative days for consideration. T. FRANCK \& E. WEISBAND, supra note 7 , at 103-04.

44. Note, supra note 20 , at $303 \&$ en 04 .

45. See 1983 HouSE REPORT, supra note 12, at 142 (listing four times concurrent resolutions introduced to disapprove sales); Gilmour \& Craig, supra note 9, at 375 (threat of veto effectively forced President to "make proposals more acceptable by adjusting numbers, eliminating components, or attaching stipulations on use of the weapons"); Moose \& Siegel, supra note 13, at 244 (legislators' valued legislative veto as threat to compel executive consultation).

46. The 1986 amendment of the AECA has made the question of severability moot. For extensive discussion of the severability question, see Note, supra note 20 , at $307-10$.

47. Congress held hearings on the AECA after Chadha, see, e.g., Legislative Veto: Arms Export Control Act, Hearing on S. 1050, Before the Senate Comm. on Foreign Relations, 98th Cong., 1st Sess. (1983); The U.S. Supreme Court Decision Concerning the Legislative Veto, Hearings Before the House Comm. on Foreign Affairs, 98th Cong., 1st Sess. (1983), but did not make a formal change in the statute until 1986; see infra note 48. 
placed the concurrent resolution provisions in the AECA with joint resolution provisions. ${ }^{48}$

These provisions, referred to as "report and wait" requirements, simply require the President to report an arms sale and then give Congress a period during which it can disapprove his action by the passage of a joint resolution, which, of course, is subject to a presidential veto. The report and wait procedure does not result in a blocked sale if one-third plus one of the members in either House can be convinced of its value. ${ }^{\text {99 }}$ Thus, under this third legislative regime, the potential for last-minute scuttling of negotiations, which made the legislative veto so powerful, is significantly diminished; so too are the incentives for meaningful executive consultation with Congress. The values served somewhat effectively under the second regime are served even less well by the third regime.

The 1986 sale of arms to Saudi Arabia dramatically demonstrated this point. ${ }^{\text {so }}$ Although a majority in both Houses of Congress voted for a resolution disapproving the sale negotiated by the executive branch, the President was ultimately able to convince 34 Senators not to oppose his veto of the resolution, leaving the Senate one vote short of overriding his veto. ${ }^{51}$ In response to the Saudi sale, Senator Joseph Biden and Representative Mel Levine recently proposed legislation which would require the executive branch to submit all major sales of sensitive weapons and equipment, except sales to American allies, to Congress for a joint resolution of approval. ${ }^{52}$ This proposal, while overcoming the most obvious flaw in the report and wait system, the difficulty of overriding a veto, ${ }^{53}$ does not address the remaining problem-the lack of early congressional participation in the decisionmaking process. ${ }^{54}$ Presentation of a sale after the negotia-

48. Amendment to the International Security Assistance and Arms Export Control Act, Pub. L. No. 99-247, 1986 U.S. CoDE Cong. \& ADMIN. News (100 Stat.) 9. Even before passage of this amendment, the legislative veto provisions were being treated as severable and executive branch officials had explicitly agreed to continue following informal pre-notification procedures as well as statutory reporting procedures. Note, supra note 20, at 317 .

49. Madison, supra note 32, at 669 .

50. See Note, supra note 20, at 322-25 \& n.243 (describing Reagan Administration's attempts to arrange sales to Saudi Arabia and Jordan in 1985-86).

51. Madison, supra note 32, at 669. As Senator Biden pointed out, the Saudi sale was thus supported by only "one-sixth of the House of Representatives and one-third plus one of the Senate." Id.

52. Id. In testimony before the House Foreign Affairs Committee in March 1987, Representative Levine described the bill as "an attempt to restore the congressional role in arms sales 'pre-Chadha', as close as is 'constitutionally permissible." "Id. at 670 . Though the Biden-Levine proposal has been dormant in committee since the March 1987 hearings on the bill, its sponsors maintain that they plan to reintroduce it this year. Telephone interview with Bill Marx, Legislative Assistant to Rep. Mel Levine (Jan. 27, 1988).

53. The President would probably not veto a sale he has submitted for approval.

54. Indeed, the assumption that Congress can only participate in policymaking after negotiations are complete may help explain why those who claimed the legislative veto would restructure foreign policymaking to include greater participation by Congress were wrong in assessing its projected usefulness. One student commentator, see Note, supra note 20 , at 327, discusses the timing of congressional participation, but makes an assumption inherent in the Biden-Levine proposal-that the only choice is between a system of congressional approval or disapproval after negotiations are complete 
tions have been completed, whether for positive approval or negative challenge, does not allow for a full congressional role in policymaking. ${ }^{55}$ If members of Congress are willing to take their constitutional responsibility to participate in this process seriously, ${ }^{66}$ then they should look for procedures that require their participation in approving the initiation as well as the conclusion of negotiations, ${ }^{57}$ while preserving executive flexibility and credibility. This balance has been managed with great success in the trade area and the mechanisms employed can inform a re-evaluation of the arms sales statutory regime.

\section{The Lessons of Fast-Track and Trade Legislation}

\section{A. Trade Statutes as a Legislative Analogue}

Trade law and arms sales law share many similar features. Trade, like arms sales, is a foreign affairs area of concurrent constitutional authority between the President and Congress; ${ }^{58}$ trade policy, like arms sales policy, is ultimately determined by the agreements that structure the exchange of goods and services. In legislating grants of authority to the executive branch for the negotiation of trade agreements, Congress must balance the same executive demands for flexibility and credibility with the congressional desire for oversight and participation.

However, similar experimentation with various legislative regimes has led to a different procedural structure in the trade area. Early trade legis-

(which is then of course subject to a possible presidential veto). After reviewing two controversial arms sales and congressional responses to them, the Note concludes that Congress will act "in an ad hoc fashion in response to specific domestic pressures" and will otherwise not want to be involved. Id. at 326-27. However, the system as it is now structured produces such a response. The writer seems aware of this possibility when he remarks that Congress may enter the process too late to have any effective influence. Id. at 327; see also Gilmour \& Craig, supra note 9, at 375-76 (Congress can only overcome inertia to not review sales under legislative veto system in response to domestic pressure or media attention). Discussion should not only focus on the merits of approval versus disapproval of executive branch action, but also on what it takes to make a congressional vote effective. This Note rejects the efficacy of an affirmative vote after negotiations are completed by the executive branch precisely because such a vote appears no more effective than a negative ex post vote. See id. at 384 (replacing legislative veto with joint resolution of disapproval or nonbinding concurrent resolutions may allow Congress some leverage but will not provide "regularized participation").

55. Cf. Meyer, supra note 7, at 84 (discussing development of increasingly formal consultation procedures in foreign assistance statutes to force meaningful consultation before executive branch commitments are made).

56. See Henkin, supra note 7, at 290 (framers saw Congress as "the principal 'policymaking'. . . organ in foreign as in domestic affairs"); Meyer, supra note 7, at 94 (arguing that Congress should "draw on the political legitimacy of its constitutional role" in institutionalizing its participation in foreign affairs); see also T. FRANCK \& E. WEISBAND, supra note 7, at 9 (willingness of individual legislators to "devote the necessary time and attention to their new foreign policy responsibilities" as vital to success of congressional participation in decisionmaking).

57. Cf. Henkin, supra note 7, at 294-95 (Congress generally "more successful" when asserting "breadth of its own powers" than when attempting to statutorily limit those of President).

58. See Koh, supra note 7, at 1192-93 (reviewing constitutional competence of both branches in trade area). As in arms sales, it is unlikely that either branch will try to act independently in the trade area because of the political consequences of such action. Id. at 1199-1200 (discussing congressional reaction to presidential reliance on independent authority in accepting Kennedy Round trade agreements). 
lation delegated broad advance authority to the President to negotiate trade agreements. ${ }^{59}$ Only after passage of the Trade Expansion Act in $1962^{60}$ was the President required to submit the agreements to Congress for subsequent approval. ${ }^{61}$ In the 1970's, as Congress revisited the statutes that had delegated such broad power to the President in foreign affairs, they passed comprehensive new trade legislation, the Trade Act of $1974 .{ }^{62}$ The legislation was intended to institutionalize congressional participation in the agreement-making process while preserving executive branch negotiating flexibility and credibility at the bargaining table. ${ }^{63}$ However, in addition to relying on the legislative veto and other tested procedural mechanisms, ${ }^{64}$ they incorporated a new procedure, the fast-track guarantee.

\section{B. The Fast-Track Guarantee in Practice}

The fast-track guarantee procedure allows Congress to delegate general negotiating authority while retaining some power to influence what is to be conceded in negotiations. The procedure represents a bargain struck with the executive branch: If the negotiated results meet with congressional approval during a ninety-day period prior to the formal signing of an agreement, then both Houses guarantee that any implementing legislation needed to activate the agreements will be sent through Congress on an expedited schedule. ${ }^{65}$ Put another way, in order to secure a guarantee of expedited treatment, the executive branch must consult with the appropriate congressional committees before the agreements are finalized.

Expedited treatment is assured by modifications in existing House and Senate rules, specifically, automatic committee discharge after 45 days, no floor amendments, and limited floor debate. ${ }^{88}$ The procedure may best be

59. See I. Destler, American Trade Politics 57 (1986) (delegation "protected legislators from one-sided restrictive pressures" of their constituents, thereby allowing "successive presidents to maintain and expand the liberal trade order").

60. Pub. L. No. 87-794, 76 Stat. 872 (1962).

61. Koh, supra note 7, at 1197-99.

62. Pub. L. No. 93-618, 88 Stat. 1978 (1975) (codified at 19 U.S.C. $\S \S 2101-2487$ (1982)).

63. The legislation was meant to assure foreign negotiators that specific concessions agreed to by American negotiators would stand a good chance of acceptance by Congress. The difficulty the executive branch faced regarding implementation of the Kennedy Round nontariff barrier agreements in the late 1960's led some foreign governments to question the credibility of United States negotiators in future trade negotiations. See Cassidy, Negotiating About Negotiations: The Geneva Multilateral Trade Talks, in The Ththered Presidency 264, 265-66 (T. Franck ed. 1981); Jackson, United States Law and Implementation of the Tokyo Round Negotiation, in J. JACkson, J. LouIS \& M. Matsushita, Implementing the Tokyo Round: National Constitutions and InteRnaTIONAL, ECONOMIC RuLES 147 \& n.47 (1984).

64. See Koh, supra note 7 , at 1200-08 (describing procedures in 1974 Act meant to impose greater control on executive branch and ensure congressional participation in upcoming Tokyo Round of multilateral trade negotations).

65. See Trade Expansion Act of 1974, 19 U.S.C. $§ \S 2112,2191$ (1982) (first fast-track legislation); Koh, supra note 7, at 1202-03 (describing provisions of legislation in detail).

66. 19 U.S.C. $\$ 2191$ (1982). Expedited procedures similar to these appear in other foreign affairs legislation. They are often used to allow quick consideration of resolutions of disapproval that 
described as a "bargain" because it is primarily a power-sharing mechanism that is not likely to be enforced in court, but rather represents a norm of expected conduct. ${ }^{67}$ Additionally, unlike the legislative veto, it allows Congress to exert pressure on the executive branch while still meeting the constitutional requirements of bicameralism and presentment.

The procedure has worked because it meets the executive branch's need for credibility through the promise of quick consideration of implementing legislation; it does so in exchange for effective and ongoing consultation with Congress, which meets the congressional goals of oversight and participation. ${ }^{68}$ An additional reason for its success may be that there are substantial incentives to work within the guarantee framework at all phases of the negotiations. For example, if the President decides to negotiate a trade agreement on his sole authority or has concluded negotiations on an agreement that was initially denied expedited treatment, his only choice would be to submit the legislation on the normal, unexpedited track, or seek "ad hoc" fast track consideration. In essence, by negotiating without receiving congressional approval for his initiatives, he takes the risk that he will not be able to deliver an implementable deal. ${ }^{69}$

Further, Congress not only enhances the likelihood of effective consultation by offering fast track consideration during negotiations, but it can continue to exert pressure for consultation by raising the threat of a revoked guarantee. If Congress feels the executive branch is not complying

may be proposed during a report and wait period. However, while they are often referred to as fasttrack procedures, they do not contain the "guarantee" element that characterizes the use of expedited procedures in the trade area and thus would seem to be less effective in promoting consultation. See, e.g., War Powers Resolution of 1973, Pub. L. No. 93-148, \& 7, 87 Stat. at 557-58 (1973); Arms Export Control Act of 1976, § 211(a), 90 Stat. at 743 (motion in House for consideration of concurrent resolution of disapproval treated as "highly privileged" on floor); id. at $\S 601(\mathrm{~b}), 90$ Stat. at 765-66 (Senate procedures for similar resolutions to receive limited committee consideration, limited floor debate and no amendments); see also Meyer, supra note 7, at 84-85 (describing combination of shortened authorization periods and expedited procedures in recent foreign aid legislation).

67. See Meyer, supra note 7, at 91-92 (discussing problem of congressional standing and judicial reticence to enter congressional-executive disputes on management of foreign affairs).

68. The procedure worked well to facilitate implementation of the most recent multilateral trade negotiations, the Tokyo Round agreements, and ensured that congressional concerns were considered by American negotiators before negotiations were concluded. After President Carter gave Congress 90-day notice of his intent to sign the Tokyo Round agreements, the executive branch negotiators consulted with the House Ways and Means and Senate Finance Committees during that period and received congressional approval on the pending agreements. A novel procedure was adopted during the 90 days. Executive branch officials participated with committee representatives in sessions similar to the "mark-up" and "conference" stages that characterize the normal legislative procedure for the drafting of bills. Thus, the drafting of the legislation became an "interbranch process." I. DestLeR, supra note 59 , at 65 ; J. JACKSON, J. Lovis \& M. MATsushitA, supra note 63, at 162-63. As a result of this new procedure, Congress passed legislation necessary to implement the nine multilateral agreements reached during the Tokyo Round negotiations in 34 legislative days. Koh, supra note 7, at 1203; see also J. Jackson, J. LouIS \& M. MATSUSHITA, supra note 63, at 166 (congressional praise for procedure clear from committee reports, legislative history and fact that it was extended by 1979 Act for eight years).

69. Of course, Congress might also decide that it favored the agreements reached and agree to pass implementing legislation. The procedure creates incentives to produce a certain norm of conduct but does not preempt other alternatives. 
with the procedural requirements of the guarantee or is not giving adequate weight to congressional suggestions, dissatisfied legislators can "derail" the fast track, revoking the guarantee at a later date for the same reasons. ${ }^{70}$ Alternatively, a later Congress can always countermand the rules adopted by an earlier Congress. ${ }^{71}$

\section{Further Refinements}

While Congress was attempting to cope with the loss of the legislative veto in the arms sales area, ${ }^{72}$ it was concurrently refining the guarantee procedure in the trade area to force executive consultation with congressional committees earlier in the negotiation process. The Trade and Tariff Act of $1984^{73}$ allows Congress to withhold a guarantee of fast-track treatment for trade agreements before formal negotiations have begun. ${ }^{74}$ Earlier fast-track legislation did not require consultation with congressional committees until the negotiations were entering their final stages.

Under this pre-negotiation procedure, if the President decides to initiate formal negotiations with a trading partner and if the executive branch seeks a fast-track guarantee for the negotiated agreement, then consultation with the appropriate committees is required. Members of these committees can force the President to take congressional concerns seriously by threatening to withhold the fast-track guarantee unless certain congressional concerns are addressed in the agenda for negotiation. ${ }^{75}$ Further, the

70. Such "derailing" of expedited procedures was suggested by Congressmen unhappy with the state of negotiations between the United States and Canada over the Free Trade Agreement. Telephone Interview with Judith H. Bello, Deputy Legal Counsel, Office of the United States Trade Representative (Jan. 28, 1988); see also Meyer, supra note 7, at 99 n.141 (expedited procedure derailed in aid context).

71. While each House may commit itself by statute to alterations of its internal rules, the constitutional authority of each house to determine the rules of its proceedings, as guaranteed by the Constitution, U.S. ConsT. art. I, $\S 5$, suggests that the procedures may be changed at a later date. See Meyer, supra note 7, at 99 n.141 (describing "derailing" of expedited procedure by member of House Committee on Rules by introducing another "highly privileged" resolution); Breyer, supra note 12, at 794 (future Congress might repeal expedited procedural rule if unhappy with executive action). But see H. REP. No. 257, 98th Cong., 1st Sess. 5 (1983) (presenting argument that statute binds Congress to change in rules).

72. See supra text accompanying notes 46-57.

73. Pub. L. No. $98-573, \S 248,98$ Stat. 2948, 2998 (amending 19 U.S.C. $\S \S 1330(d)(4)$, 2192(a)(1)(A), 2253(c) (1982)).

74. Briefly, the legislation provides that if the President seeks to negotiate a bilateral trade agreement, he must notify and consult with key congressional committees for a period of 60 legislative days before giving the 90-day notice of his intent to sign the agreement required under the older fast-track procedure. If neither committee disapproves of the pending negotiations or of executive objectives in negotiating an agreement, then any negotiated agreement submitted 90 days before signing will be eligible for fast-track consideration when submitted after signing. 19 U.S.C. $§ 2112$ (b)(4) (1982). In theory, the President could begin negotiations and then notify the committees 150 days before the proposed signing date. However, the Reagan administration has chosen to construe the provision as requiring committee consultation 60 legislative days before the commencement of formal negotiations. Koh, supra note 7 , at 1213 n.64.

75. The shift to a pre-negotiation guarantee procedure clearly magnifies the influence of the committees concerned. Even under the less restrictive fast-track procedure, these committees proved the focus of executive branch attention. I. DESTLER, supra note 59, at 65 (citing need of executive branch 
procedure provides incentives for the executive branch to continue effective consultation with the committees because Congress retains two chances to disapprove the results at the post-negotiation stage: The committee in either House can recommend disapproval of the implementing legislation and, even if it receives approval of both committees, either House can vote it down.

Denial of a fast-track guarantee at this stage allows Congress significant impact on policy formulation. Disapproval by either of the two congressional committees may destroy executive branch credibility before negotiations have even begun. ${ }^{78}$ The pre-negotiation procedure clearly makes the decision of whether to proceed with negotiations one that is shared by the two branches. It allows Congress to participate in setting the negotiating agenda while still preserving executive flexibility at the bargaining table. Further, it enhances executive credibility overall because negotiators know, broadly speaking, what concessions are acceptable to Congress.

\section{A Proposal for Arms Sales Legislation}

The fast-track guarantee provides expedited legislative treatment in exchange for meaningful congressional input into negotiations. Generalizing from experience in the trade area, the procedure may prove effective in ensuring congressional input in other foreign policy areas where three conditions exist. First, the procedure will be most successful politically in areas where, because of a constitutional claim to competence, Congress can exact some price in the form of consultation in exchange for its broad grants of authority to the executive branch. Second, the procedure can be applied in any area where the executive branch acts through agreements with foreign nations. Third, the executive agreements amenable to the fast-track procedure must require some legislative action, in the form of implementing legislation or some approval or disapproval procedure, to take effect.

The procedure thus provides a way for Congress to police the use of executive agreements in certain foreign affairs situations. It provides the added benefit of assuring the President that, when he makes such executive agreements, his actions will have the support of Congress. Though a number of foreign policy areas meet the three criteria outlined above, ${ }^{27}$

negotiators in 1979 for "the committees' overwhelming support of the agreements negotiated"). The solution to this problem may simply be to involve more committees or provide by statute that the key committees take into consideration the views of non-voting committees.

76. Lacking the pre-negotiation fast-track guarantee procedure, Congress could still register disapproval of proposed negotiations by passing a "sense of the Congress" resolution stating that it does not agree with the substance of ongoing negotiations or that it plans to withhold implementing legislation. But it could not send such a strong and potentially devastating message to the President at the outset of negotiations.

77. See infra Section III B. 
congressional regulation of arms sales seems a particularly appropriate area for experimentation.

\section{A. Making Arms Sales Legislation More Effective}

When the President agrees to sell arms to a foreign government, he is acting in an area where he shares constitutional authority to act with Congress. The nature of arms sales requires Congress to delegate broad authority to the executive branch to negotiate the sales arrangements. Acting under this delegated authority and any independent authority he may claim, the President then makes executive agreements in the form of offers to sell arms packages. ${ }^{78}$ Thus, arms sales meet the first two criteria discussed above. Further, since the passage of the AECA in 1976, Congress has required that arms sales be subject to some further congressional action. Although the two procedures tried-the legislative veto and the report and wait period-have provided only the threat of disapproval (with the latter procedure subject to a presidential veto), the fact that negotiated sales have been consistently brought before Congress provides the type of legislative involvement the fast-track guarantee requires.

Under current legislation, by the time congressional acquiescence is sought, agreement with a foreign buyer has been reached and severe diplomatic repercussions may result from an ex post congressional challenge. ${ }^{79}$ Further, an ex post procedure, whether it involves necessary approval or discretionary disapproval, does not directly force the executive branch to consult with Congress during negotiations. Thus, if legislators are willing to take their constitutional role seriously, they should consider adopting a pre-negotiation fast-track guarantee procedure to regulate such transfers. Increased exercise of this responsibility may in fact redound to the benefit of the executive branch by creating a broader legitimacy for the arms sales that are negotiated. ${ }^{80}$

As soon as executive branch officials decide to initiate negotiations with a foreign buyer, they should be required to consult with appropriate congressional committees, most likely the Senate Foreign Relations Commit-

78. See Warnke \& Luck, supra note 13, at 216-17 (describing informal negotiation process in greater depth).

79. See T. Franck \& E. Weisband, supra note 7, at 101-03 (describing King Hussein's refusal to provide executive branch with "face saving formula" when Congress threatened legislative veto of finalized sale in 1975). Commentators have also noted that the current disapproval system may prove completely ineffective because individual members will not want to run the risk of embarrassing the United States government. See Moose \& Siegel, supra note 13, at 253-54.

80. See T. Franck \& E. Weisband, supra note 7, at 8 ("When Congress challenges the President, it focuses his attention on the task of convincing the public, of "bringing the country along." "). The potential benefit to the executive branch should not be underestimated. See Gilmour \& Craig, supra note 9, at 376 (President may benefit from including Congress in controversial decisions because he will not bear sole responsibility for denial of sales); T. FRANCK \& E. WEISBAND, supra note 7, at 105-11 (effect of increased congressional participation in arms sales in 1976-79 period has been legitimization of sales). The executive branch will remain in control at the negotiating table, with credibility to back up its offers, as long as it keeps Congress informed of any new developments. 
tee and the House Committee on Foreign Affairs. ${ }^{81}$ The committees could then approve the sale and guarantee that the final letter of offer would receive fast-track consideration, or they could deny the guarantee, thereby subjecting a submitted letter of offer to consideration under normal legislative procedure. Legislators should consider requiring a joint resolution of approval for large negotiated sales and commercial export licenses. ${ }^{\mathbf{2}}$ The requirement of positive approval for large sales would make denial of a fast-track guarantee at the pre-negotiation stage potentially devastating for the negotiations because executive branch negotiators would then have no way to ensure the buyer that the sale would in fact be approved by Congress. ${ }^{83}$ However, executive branch officials, willing to adjust their perspective agenda for the sale, might be able to convince the committees to give a guarantee to modified proposed arms package. ${ }^{84}$

A fast-track guarantee procedure for arms sales will allow the values of congressional oversight and participation to be met while still allowing executive branch flexibility in arranging and implementing arms deals. ${ }^{85}$ Debate over specific sales should also allow both branches to address the broader policy question of how the United States government should approach the growing demand for arms among developing countries. For example, increased congressional participation in regulating arms trans-

81. Given the informal nature of many such discussions, it may be more difficult here than in the trade area for Congress to specify when consultation should begin. Yet it seems clear that in the case of either government or commercial sales, there are certain procedures that indicate the start of the formal authorizing process. See Moose \& Siegel, supra note 13, at 216-17.

82. The suggested change will necessarily increase the workload of an already overburdened Congress. Madison, supra note 32, at 667; Note, supra note 20, at 327. Committee workload will increase because of a need to respond to executive branch requests for fast-track consideration. Additionally, once letters of offer and commercial licenses are extended, congressional approval in the form of a joint resolution will be required for a sale to be completed. One way to limit the workload would be to allow the exccutive branch to forgo the procedure for sales under a certain threshold level. Even with a low threshold, many sales will be quickly approved as relatively non-controversial. Under the current system, a floor vote is always a possibility because any member can typically introduce a motion for a joint resolution. Under the fast-track system, a vote, although obligatory, is guaranteed to take place immediately and consume a minimum amount of time.

83. The current ex post disapproval procedure could also be adapted to accommodate a fast-track guarantee. For example, Congress could give a pre-negotiation guarantee that it would allow the report and wait period to lapse, thereby guaranteeing that the arms deal would not encounter later legislative obstacles. The requirement of a joint resolution of approval simply puts the burden on the executive branch to convince Congress to support an arms deal.

84. A more radical suggestion, which would constrain the executive branch even further, would be to revise the appropriation procedure such that Congress would not only have to approve the pending sale but also authorize the release of funds to procure any equipment from defense contractors. This sort of "implementing" legislation might force the executive branch to be more amenable to early congressional input, but it would undoubtedly result in a slower and less efficient process in general.

85. Congress has traditionally included emergency waiver provisions in arms sales legislation. Such waiver provisions allow the executive branch ample flexibility to respond to emergencies. The waiver provisions in the AECA allows resort to the waiver in cases of "exceptional circumstances" or when it would be "in the national interest". See Scheffer, supra note 2, at 698-713 (discussing vague wording of waiver provision). Obviously, the vague language used in such a waiver provision provides a potentially enormous loophole for the executive branch; in the wake of the Iran-Contra affair, such loopholes may be addressed by Congress. 
fers may allow Congress to force executive compliance with the mandate of sales restraint set out in the AECA. ${ }^{86}$

\section{B. Potential Application in Other Areas}

Given that there are many foreign affairs areas where the executive and legislative branches claim concurrent constitutional authority to make policy, the guarantee procedure may be applied in other foreign affairs legislation to allow a new balance to be established between congressional participation and executive flexibility.

There are numerous areas where Congress delegates broad authority to the President to manage a foreign policy area and where the President resorts to executive agreements to implement foreign policy decisions. When executive branch officials engage in negotiation with a foreign government to establish a commitment for the United States to act-be it to spend money, arrange an export license, procure goods, or send troops abroad-the agreement and the negotiations leading up to it may well involve an area of congressional competence, although the agreementmaking process may be informal. Further, once an agreement has been negotiated, there are a number of ways Congress can condition actual implementation on its acquiescence. In the trade area this is done through formal implementing legislation which alters domestic law. More generally, agreements of some import, such as large arms sales or nuclear exports, may be subject to a congressional approval or disapproval period before they become activated.

Although a thorough review of all the potential applications of the fasttrack guarantee procedure is beyond the scope of this Note, a few comments can be made. The procedure should not be used to condition executive action in areas in which the President's power to act independently is strong, such as the recognition of governments or the settlement of claims, because the constitutional authority that supports it as a power-sharing mechanism is lacking in these cases. Additionally, it is not likely to be effective in those situations where the President must respond to emergency situations either by making military decisions regarding troop deployments or by exercising his "emergency economic powers." Finally, certain areas, notably foreign assistance, may be ill-suited to the type of give and take the guarantee procedure requires. Aid decisions can not be considered negotiated; they are highly discretionary once Congress has set

86. Congress, in passing the AECA in 1976, made a strong policy declaration regarding the export of arms manufactured in the United States. See supra note 8. If in fact the majority of legislators still feel this policy should guide executive branch initiatives, then the fast-track guarantee procedure will provide a means for legislators to ensure that the executive branch includes the goal of general restraint in its calculus. If this policy no longer commands majority support, the procedure can be used to support a more aggressive executive branch stance. Whether a policy of restraint or active sales is pursued, the procedure will provide a way to scrutinize individual sales for their contribution to the overall goals being pursued by the United States government in this area. 
funding levels and objective standards. Consultation in this area is probably better handled by resort to a variety of other mechanisms, such as shortened authorization periods combined with expedited procedures for termination of aid. ${ }^{87}$

However, statutes involving the export of weapons, nuclear materials and sensitive technologies all typically involve agreements made with foreign governments and could be subject to a fast-track guarantee procedure. Other agreements to participate in bilateral or multilateral undertakings, such as agreements to establish or renew foreign military bases, could also be handled under the procedure. In each case, Congress will have to assess whether the balance established under broad delegation is preferable to the balance established with a power-sharing mechanism like the fasttrack guarantee procedure.

\section{Conclusion}

Without the legislative veto, the statutory framework for congressional regulation of arms sales provides little incentive for the executive branch to consult with Congress before a sale becomes final. The fast-track guarantee procedure, which has been used for over a decade in trade legislation to guarantee congressional participation in trade negotiations, can be adapted to the arms sales area. The procedure will allow Congress to register its approval or disapproval of any potentially controversial sale before a foreign government has been promised the arms. Further, it will also allow Congress to better monitor executive branch compliance with the mandate of AECA, requiring the United States government to exercise restraint in its arms sales policy. More generally, application of the procedure to the arms sales area will demonstrate its efficacy outside the trade area and may prompt adoption of the procedure in other foreign affairs legislation where Congress seeks to recalibrate the balance between congressional participation and executive flexibility. 
